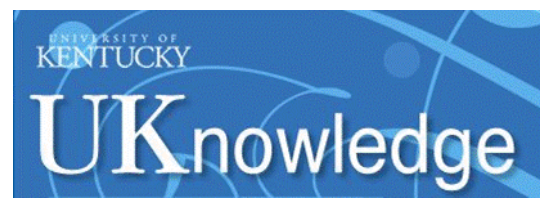

University of Kentucky

UKnowledge

$9-2015$

\title{
Nurturing University Students to be Social Entrepreneurs: Relevance of Service Leadership Education
}

\author{
Daniel T. L. Shek \\ University of Kentucky \\ Li Lin \\ Hong Kong Polytechnic University, China
}

Follow this and additional works at: https://uknowledge.uky.edu/pediatrics_facpub

Part of the Pediatrics Commons

Right click to open a feedback form in a new tab to let us know how this document benefits you.

\section{Repository Citation}

Shek, Daniel T. L. and Lin, Li, "Nurturing University Students to be Social Entrepreneurs: Relevance of Service Leadership Education" (2015). Pediatrics Faculty Publications. 211.

https://uknowledge.uky.edu/pediatrics_facpub/211

This Article is brought to you for free and open access by the Pediatrics at UKnowledge. It has been accepted for inclusion in Pediatrics Faculty Publications by an authorized administrator of UKnowledge. For more information, please contact UKnowledge@lsv.uky.edu. 


\section{Nurturing University Students to be Social Entrepreneurs: Relevance of Service Leadership Education}

\section{Digital Object Identifier (DOI)}

https://doi.org/10.1515/ijdhd-2015-0409

\section{Notes/Citation Information}

Published in International Journal on Disability and Human Development, v. 14, no. 3, p. 285-293.

(C) 2015 Walter de Gruyter GmbH, Berlin/Boston

The copyright holders have granted the permission for posting the article here. 
Daniel T.L. Shek* and Li Lin

\section{Nurturing university students to be social entrepreneurs: relevance of service leadership education}

DOI 10.1515/ijdhd-2015-0409

Received May 10, 2014; accepted June 23, 2014; previously published online August 12, 2015

\begin{abstract}
When the concept of social entrepreneurship becomes more popular, many universities explicitly claim that they wish to nurture social entrepreneurs. In this paper, the concept of social entrepreneurship and the successful attributes of social entrepreneurs are outlined. With reference to the question of how university students can be nurtured to be social entrepreneurs, it is suggested that the service leadership model proposed by the Hong Kong Institute of Service Leadership and Management is a good framework to be considered. In the framework, it is asserted that there are three attributes of a successful service leader - leadership competence, moral character, and caring dispositions. In this study, the experience of implementing a credit-bearing subject based on the service leadership model at The Hong Kong Polytechnic University is highlighted.
\end{abstract}

Keywords: effective leadership; higher education; service leadership; social entrepreneurship.

\footnotetext{
${ }^{*}$ Corresponding author: Daniel T.L. Shek, PhD, FHKPS, BBS, SBS, JP, Associate Vice President (Undergraduate Program), The Hong Kong Polytechnic University, Room HJ407, Core H, Hunghom, Hong Kong, PR China; Department of Applied Social Sciences, The Hong Kong Polytechnic University, Hong Kong, PR China; Centre for Innovative Programmes for Adolescents and Families, The Hong Kong Polytechnic University, Hong Kong, PR China; Kiang Wu Nursing College of Macau, Macau, PR China; School of Social Development, East China Normal University, Shanghai, PR China; and Division of Adolescent Medicine, Department of Pediatrics, Kentucky Children's Hospital, University of Kentucky College of Medicine, Lexington, Kentucky, USA, E-mail: daniel.shek@polyu.edu.hk Li Lin: Department of Applied Social Sciences, The Hong Kong Polytechnic University, Hong Kong, PR China
}

\section{Introduction}

Although there are many different conceptions and definitions of "social entrepreneurs," it is commonly conceived as "some person or group: 1) aim(s) at creating social value, either exclusively or at least in some prominent way; 2) show(s) a capacity to recognize and take advantage of opportunities to create that value ("envision"); 3) employ(s) innovation, ranging from outright invention to adapting someone else's novelty, in creating and/or distributing social value; 4) is/are willing to accept an aboveaverage degree of risk in creating and disseminating social value; and 5) is/are unusually resourceful in being relatively undaunted by scarce assets in pursuing their social venture" $[1$, p. 64]. In the past decades, research, dialogues, and publications on this topic in the academic and professional communities have been on the rise. In fact, social entrepreneurship has been manifested in different domains including economic, educational, political, welfare, environmental fields [2, 3]. A common belief is that when government effort is not that effective to solve social problems, such as poverty, and charity cannot fundamentally relieve the suffering, social entrepreneurship, which is more flexible, innovative, and pragmatic while also compassionate, is regarded as a promising response to improve our society [2].

The growth of social entrepreneurship demands nurturing plenty of social entrepreneurs who initiate process of making social changes [4]. These people are commonly expected to possess specific qualities such as creatively delivering their services to a segment of society while fulfilling their social mission [5]. Besides, it is also expected that social entrepreneurs are visionary leaders who have passion about the vulnerable groups and social problems in a society. As such, a fundamental question that educators should ask is how we can nurture students to be social entrepreneurs by building up their foundational competencies and qualities of social entrepreneurs. Generally speaking, to be a successful social entrepreneur, a person must have knowledge in different disciplines, such as economics, business, social policy, politics, public relations, 
community building and social welfare, and community psychology. Most of the time, such knowledge base demands integration and cross-fertilization of knowledge in different fields. Besides the academic and professional knowledge, social entrepreneurs are also expected to have passion about people, a sense of social vision, other-orientation, integrity and morality which are the backbone and spirit of social entrepreneurship. In fact, one may argue that these qualities are even more important than the cross-fertilized knowledge.

In this chapter, it is argued that development of leadership qualities of university students provides the necessary foundation for nurturing social entrepreneurs. Although there are different leadership models in the field, the present discussion is focused on the qualities of leaders within the Service Leadership model proposed by the Hong Kong Institute of Service Leadership and Management (HKI-SLAM). The characteristics demanded by social entrepreneurship, such as other-orientation and discipline and accountability, correspond to the ideas of service leadership, which is defined as "about satisfying needs by consistently providing quality personal service to everyone one comes into contact with, including one's self, others, groups, communities, systems, and environments" [6, p. 5]. As such, we believe that the education and training of service leadership can prepare university students for developing the foundational qualities of social entrepreneurship. Against the above background, there are several sections in this chapter. First, the conceptualization of social entrepreneurship and social entrepreneur is outlined. Second, qualities of "successful" social entrepreneurs are discussed. Third, the relationship between social entrepreneurship and service leadership is addressed. Finally, a subject entitled "Service Leadership" piloted at the Hong Kong Polytechnic University and the preliminary evaluation findings are presented.

\section{Conceptualization of social entrepreneurship and social entrepreneurs}

Although there is a heated discussion of social entrepreneurship or social entrepreneurs in the public, mass media, and scientific literature, the related definitions of the concept range from narrow to broad without a consensus. In the initial discussion of the concept, "social mission" was regarded as an explicit and central component of social entrepreneurship [7]. Specifically, Dees integrated four streams of thoughts on entrepreneurship [8-11] with his own ideas and proposed five roles of social entrepreneurs who are leaders demonstrating social entrepreneurship. First, drawing from Say's perspective [8] on entrepreneur as the one creating value, he believed that social entrepreneurs should aim at creating and sustaining "social value" rather than merely "private value". It is the fundamental characteristic that distinguishes social entrepreneurs from commercial entrepreneurs [12]. Second, similar to Schumpeter [9], he contended that social entrepreneurs should focus on making changes or innovations "by serving new markets or creating new ways of doing things" [9, p. 2]. Social entrepreneurs are regarded as reformers and revolutionaries who are seeking to make fundamental and systemic transformation in order to solve the social problems. Third, akin to Drucker's notion [10], he considered that social entrepreneurs are able to recognize the opportunity from problems and persistently pursue new opportunity. In other words, a social entrepreneur has the ability to seize opportunity, to vision how to improve the adverse situation, and to consistently pursue the goal. Fourth, consistent with the assertions of Stevenson et al. [11], he believed that social entrepreneurs should not be limited by their resources at hand. Instead, they should mobilize the resources around to achieve their goals. As the social problems to be solved are presumably demanding and challenging yet with scare resource, social entrepreneurs should have the courage and capacity to expand resource, creatively use minimal resource, or even take risk in exploiting limited resource. Last but not least, he specifically proposed that discipline and accountability to the constituencies served are the features of social entrepreneurs. They strive for making a "right" thing, such as getting a "correct" understanding of the needs of people or community they are going to serve. In brief, seizing opportunity to ethically fulfill social mission via innovation is the main feature of social entrepreneurship.

The characteristics of social value creation, difference making, innovation, opportunity recognition, resourcefulness, risk taking, vision, virtuousness are adopted, if not completely, by many other researchers in their conceptualizations or descriptions of social entrepreneurship [1, 5, 13-15]. To name a few, Borenstein [14] considered social entrepreneur as a "pathbreaker with a powerful idea, who combines visionary and real world problem-solving creativity, who has a strong ethical fibre and who is totally possessed by his or her vision for change" (p. 36). For Thompson et al. [15], social entrepreneurs are people who are apt at discovering an opportunity to meet the needs that the societal welfare systems fail to meet, who can well 
utilize human and capital resource to make a difference. Sullivan Mort et al. [5] highlighted that innovativeness, proactiveness, and risk management are essential traits of social entrepreneurship. In addition, they believed that social entrepreneurship includes a virtue component which is often absent or hidden in commercial entrepreneurship. In other words, the positive and morally good values such as integrity, honesty, and empathy are upheld and social entrepreneurs should act accordingly.

The early definition of social entrepreneurship tended to focus on individual traits of leadership [16] or regarded social entrepreneurs as "one special breed of leaders" [7, p. 6]. However, Weerawardena and Sullivan Mort [17] argued for incorporating context in the conceptualization of social entrepreneurship. Based on the grounded theory approach and nine in-depth case studies of not-for-profit organizations, they proposed a more comprehensive model on social entrepreneurship. This multidimensional model of social entrepreneurship is a constrained optimization model that interprets social value creation as the product of interaction between innovativeness, proactiveness, and risk management, and is subject to sustainability, social mission, and the operating environment. Similar view can be seen from Austin et al. [12] who emphasized reaching a dynamic fit among four components, namely the people, the deal, the opportunity, and the context (e.g. demographics, macroeconomy, tax, sociocultural context).

When environmental fit is considered, the question of gaining competiveness and sustainability becomes salient. In order to fulfill the social mission in the long run, social entrepreneurs have to make a balanced judgment between mission and money $[5,18]$. With the increase of social enterprise that is tangible outcome of social entrepreneurship [4], raising funds and attracting resource become more and more competitive. A social enterprise has to compete intensively with other social entrepreneurial organizations with similar objective, or even other commercial organizations for market opportunities and resource [5, 16]. Additionally, some social enterprises would earn profit to compensate the cost in the operation process. The capital accumulating or income-generating capacity can ensure the sustainability of the organization, which renders the fulfillment of social mission possible. To this extent, social entrepreneurs are not totally different from commercial entrepreneurs, while their moneymaking capacity serves the social mission.

From the multiple definitions of social entrepreneurship/entrepreneurs, we can see that social entrepreneurs inherit the characteristics of entrepreneurs, such as creating innovative goods and service, as well as absorbing investment and generating economic return. Meanwhile, they respond to social problems and create social value. More importantly, they are not simply a mixture of entrepreneurs and social leaders. They struggle to balance social goal and commercial goal, which makes social entrepreneurship a complicated and difficult endeavor [19]. Besides, in order to thrive and fulfill the social mission, social entrepreneurs are expected to possess some foundational competencies such as resilience, adversity quotation, and perseverance.

\section{Attributes of successful social entrepreneurs}

Social entrepreneurs are entrepreneurial leaders with a social mission $[7,20,21]$. However, the innate conflict between social mission and commercial interests makes the role of social entrepreneurs difficult to fulfill. Based on the literature on the definition of social entrepreneurship or social entrepreneur $[5,7,20]$, the comparison of social vs. commercial entrepreneurship/entrepreneur [12], as well as the antecedents of social entrepreneurship [22, 23], we identified some qualities that are required to carry out successful social entrepreneurship.

First of all, social entrepreneurs should possess a set of qualities shared by business entrepreneurs [23], yet with a specific goal of creating social value. Initially, many researchers and practitioners agreed that the capacity to seize opportunity and turn the opportunity into social value through innovation is vital in social entrepreneurship [5, 7, 20, 21]. Entrepreneurs by definition are the persons who "reform or revolutionize the pattern of production by exploiting an invention or, more generally, an untried technological possibility for producing a new commodity or producing an old one in a new way, by opening up a new source of supply of materials or a new outlet for products, by reorganizing an industry and so on" [9, p. 132]. However, social entrepreneurs make innovation to achieve social value creation. They identify the problems which might not be completely solved by purely governmental, philanthropic, or commercial approaches, and work out new strategies to resolve it. Considering that they usually target at demanding social problems but with limited resource and real-life constraints [2, 12], they have to generate new product or service, and pioneer new ways of marketing and delivering product or service [5]. Concerning their survival in the competitive market, social entrepreneurs should be creative enough to win funds as long as they are creating social value [7]. Moreover, unexpectedness and uncertainty can hardly be avoided in their 
ventures, hereby they should be ready to change so as to adapt to the dynamic environment [5]. In this context, successful social entrepreneurs should possess good psychosocial competence such as cognitive competence (e.g. creativity) and innovative problem-solving skills.

Secondly, as innovation somewhat implies a risk of failure, social entrepreneurs should have a strong capacity of risk management and resiliency in adversity $[5,7]$. More importantly, as leaders in the social enterprise, they should not only motivate themselves, but also drive their followers, sponsors, partners, and other people involved in their venture to move on. Accordingly, the abilities to convey a clear vision, to communicate the mission, and to instill purpose and confidence in others are highly needed $[16,21]$. In short, resilience and emotional competence are intrinsic to a successful social entrepreneur.

Finally, the ability to build up and manage a wide range of social relations is also important for social entrepreneurs. Social enterprises usually possess limited resource including financial and human capital. For achieving their social mission, social entrepreneurs should be able to establish a rich network, including donors, funders, staff, clients, government and other partners, and maintain positive relationships with these people and organizations $[7,12,21]$. The extensive network would provide them with information, technology, talents, financial support and so forth. In addition, for accurately assessing the needs of target and process of activity, they are required to build a close connection with the target people and communities [7].

However, the aforementioned competencies are not adequate to attain successful social entrepreneurship. Economic interest and other self-interest that are pursued by business entrepreneurs cannot completely drive and sustain social entrepreneurship. What make social entrepreneurs distinctive are the following qualities concerning prosocial disposition and virtuousness.

In the first place, a successful social entrepreneur demonstrates prosocial values, emotion, and behavior [16, 22-24]. The goal of improving the life of disadvantageous people demands a prosocial motive of social entrepreneur. Ernst [23] contended that social entrepreneurs usually have prosocial disposition, which is a stable tendency to consider the well-being and right of other people, empathize with others' feelings and thought, and act accordingly for the sake of others [25]. Specifically, she argued that empathy and sense of social responsibility drive people engaging in social entrepreneurship. The empathy toward miserable people enables social entrepreneurs to recognize opportunity of change. The obligation to relief the pain also impels social entrepreneurs to make endeavor. Miller et al. [22] also regarded compassion as a strong motive of social entrepreneurship. Compassion is a prosocial emotion oriented toward others and linking an individual to a suffering community emotionally. In their opinions, compassion of social entrepreneurs increases their integrative thinking (e.g. integrating social value with economic value), their tendency to make prosocial cost-benefit analysis (e.g. relieving others' pain even at a cost to oneself), and their commitment to alleviate others' suffering (e.g. be persistent in continuing the mission in adversity). These factors altogether enhance the likelihood of engaging into social entrepreneurship. Accordingly, we believe that prosocial disposition enables social entrepreneurs to initiate a social mission, motivates them to persistently be involved into the mission, and furthermore, ensures that the needs of target are truly met in the process.

In the second place, conducting entrepreneurially virtuous behavior should be upheld in social entrepreneurship. Sullivan Mort et al. [5] believed that the attitudes and behavior of social entrepreneurs must be "morally good", which differentiates them from commercial entrepreneurs. Specifically, they should keep conscious of their actions, conduct ethical behavior for its own sake rather than external incentive, and internalize the moral values and actions. For one thing, the premise of benefiting society implies altruistic objective that impels social entrepreneurship and virtuous behavior that aims at achieving the altruistic objective. However, economic concerns and egoism sometimes make social entrepreneurs fall into a moral trap where they have to make a balanced judgment in order to sustain their social mission [26]. In addition, as "social mission" and concern for people are basic features of social entrepreneurship, social entrepreneurs must demonstrate a strong reputation of credibility, fairness, and competence in satisfying the needs of different stakeholders so as to attract their contributors and workers [12, 27]. They must build up strong trust among their contributors and workers to ensure that people are willing to invest into their projects and work with them [12].

As pointed out by Leadbeater [21], successful social entrepreneurs are "leaders, storytellers, people managers, visionary opportunists and alliance builders" (p. 53). As far storytelling is concerned, social entrepreneurs are good at communicating their stories in a compelling manner. They are also good at managing people, networking with people, and building alliance with others using language that is caring, compassionate, and moral. Finally, social entrepreneurs are visionary and they use moral language to communicate such visions. 


\section{Leadership qualities in social entrepreneurs}

Theoretically, there is an intimate linkage between social entrepreneurship and leadership. Primarily, there are views suggesting that social entrepreneurs assume leadership role (i.e. social entrepreneurs are intrinsically leaders): Sullivan Mort et al. [5] stated that "it has been suggested that social entrepreneurs provide innovative or exceptional leadership in social enterprises" (p. 81); Dees [7] even suggested that social entrepreneurs are one special breed of leaders; Thompson et al. [15] asserted that "social entrepreneurship needs some combination of people with visionary ideas, people with leadership skills and a commitment to make things happen, and people committed to helping others” (p. 332); Cukier et al. [28] also suggested that social entrepreneurs shared some characteristics with business entrepreneurs, including "leadership and charisma, risk perception/tolerance" (p. 104).

Another view is that successful social entrepreneurs possess leadership skills (i.e. leadership skills would shape successful entrepreneurs). Leadbeater [21] pointed out that leadership is an integral part of successful social entrepreneurs - "the quality that all the social entrepreneurs have in abundance is leadership. They are very good at setting a mission for an organization and mobilizing people around it. A sense of mission is vital for all non-profit organisations because it provides them with their sense of purpose...The mission is the flag around which staff, users and supporters can gather even when there is little to show by way of services or physical infrastructure...The mission has to be coherent and clear enough to command support, but flexible enough to allow growth" (p. 54). Ernst [23] outlined the attributes of social entrepreneur personality, which includes entrepreneur personality (risk-taking propensity, innovativeness, need for achievement, need for independence, proactiveness) and prosocial personality (empathy and sense of social responsibility). These traits are closely related to leadership attributes in the literature.

Intuitively, although there is an intimate link between social entrepreneurs and leadership, research in this area is far from satisfactory. Short et al. [29] analyzed prior literature about social entrepreneurship in different disciplines. They pointed out that in management realm, "examination of leadership in social ventures has received little attention in social entrepreneurship research to date" (p. 181). They believed that it is possible and necessary to explore the role of leadership in fostering social entrepreneurship values and ventures. Prabhu [16] similarly remarked that "our knowledge of social entrepreneurial leaders is inadequate" (p. 142).

Obviously, nurturing leadership qualities is an important step to build up the foundation for social entrepreneurs. There are a variety of courses of social entrepreneurship in university education. When reviewing the syllabus, Brock and Steiner [30] summarized seven essential topics: social needs/problems, innovation, scaling a social venture, resource acquisition to accomplish the organization's mission, opportunity recognition, creating a sustainable business model, and measuring outcomes. Obviously, there is a missing dimension on leadership qualities in the existing curriculum frameworks. There is an appeal to include the prosocial dimension of social entrepreneurship in educating future social entrepreneurs (e.g. empathy) [31]. Besides, Tracey and Phillips [19] pointed out that as social entrepreneurs have to manage the double bottom line (i.e. social vs. commercial objective), students should be conscious of this dilemma and the related resolution skills. Hence, the development of prosocial behavior and moral character becomes increasingly crucial for handling such a tension. Leadership education that places much or even stronger emphasis on nurturing caring disposition and cultivating moral character (vs. training competencies) among college students unquestionably echoes this call.

Using the Service Leadership model developed by the Hong Kong Institute of Service Leadership and Management, we discuss the leadership qualities that constitute foundational qualities of social entrepreneurs. According to this model [6], to lead is to serve. This is basically in line with the core spirit of social entrepreneurship serving the society with a social mission. In the Service Leadership model, it is also proposed that an effective leader possesses three basic attributes - basic leadership competencies, moral character, and caring disposition. As far as basic competencies are concerned, they are consistent with the above discussion that a successful social entrepreneur manages people and possesses resilience, good networking skills, and psychosocial competencies. Regarding moral character, this is actually the soul of social entrepreneurs. As the focus of social entrepreneurship is "not for profit", the accountability, integrity, and discipline of social entrepreneur are important. Finally, caring disposition also echoes with the emphasis of social entrepreneurship on social mission, passion, and compassion about people. In short, the attributes of an effective service leader share the characteristics of a successful social entrepreneur. Social entrepreneurship requires intrapersonal competencies such as innovativeness and 
resilience, interpersonal competencies such as ability of creating and managing diverse relationships, the compassion and empathy toward the needy and deprived people, and the moral characters to ensure the venture in the accurate way and attract more support and investment from others.

\section{"Service leadership" subject for university students}

The Hong Kong Institute of Service Leadership and Management (HKI-SLAM) was established by Po Chung [founder of DHL International (Hong Kong) Ltd.] and several founding members to promote service leadership education in Hong Kong. With the financial support of the Victor and William Fung Foundation, one initiative launched by the HKI-SLAM was to encourage and enable the eight universities in Hong Kong to utilize the SLAM framework to develop curriculum materials on service leadership. As Chung [6] stated, "the proximal goal of the HKI-SLAM is to develop and produce curriculum and sustainable educational practices that can bring about paradigm shifts in teachers, learners, and citizens' mindsets and frames of mind about leadership, service, and service leadership" (p. 3). There are seven core beliefs in the HKISLAM model as follows:

1. Core Belief 1: "Leadership is a service aimed at ethically satisfying the needs of self, others, groups, communities, systems, and environments".

2. Core Belief 2: "Every day, every human occupies a position of leadership and possesses the potential to improve his or her leadership quality and effectiveness".

3. Core Belief 3: "Leadership effectiveness and service satisfaction are dependent on a leader or service provider possessing relevant situational task competencies plus being judged by superiors, peers, and subordinates as possessing character and exhibiting care".

4. Core Belief 4: "Service includes self-development efforts aimed at ethically improving one's competencies, abilities, and willingness to help satisfy the needs of others".

5. Core Belief 5: "Service leadership is about creating appropriate personal service propositions in real time and constantly striving to provide the highest quality service one affords to everyone one comes into contact with and whose lives are affected by one's actions or leadership".
6. Core Belief 6: "Service leadership is the world's oldest, most competitive, and longest surviving business model".

7. Core Belief 7: "High-paying, high status positions and management promotions will go to people who have domain specific knowledge and skills plus service leadership competencies, appropriate character strengths, and a caring social disposition".

While these core beliefs are strongly linked to the growing service economy which may not be totally related to social entrepreneurship (e.g. Core Beliefs 6 and 7), the first five core beliefs, particularly the three basic attributes of effective service leaders (i.e. competence, character, and caring disposition), are highly relevant to social entrepreneurship. Besides the core beliefs, essential curriculum content, knowledge, skills, values and attitude strands are also intrinsic to the HKI-SLAM model. The spirit of the service leadership model can be summarized in the Service Leader's pledge as follows [6]:

\begin{abstract}
"I am the entrepreneur of my life. My success will be heavily influenced by my task competencies, character strengths, and caring disposition towards others. Whatever I do to promote my success, above all else, I am in the business of providing the highest quality ethical service I can afford to everyone I come in contact with or whose life is affected by my actions or by my leadership" (p. 4).
\end{abstract}

Based on this curriculum framework, a subject entitled "Service Leadership" was developed at The Hong Kong Polytechnic University. The following topics are included in the subject [32]:

1. Introduction: concepts related to service leadership; nature and rationales of service leadership; service industry and service leadership; relevance of service leadership to university students and graduates in Hong Kong.

2. Core beliefs about service leadership; service leadership as a function of leadership competencies, moral character and care [E (Effective Service Leadership)= $\mathrm{MC}^{2}$ (Moral character $\times$ Competence $\times$ Care)]; ultimate goals of service leadership education; essential knowledge, skills, and attitudes and value strands.

3. Three realms of leadership (self-leadership, teamleadership, service habitats); systems thinking, interdisciplinary collaboration; leadership in a historical perspective; evolutionary origins of leadership; and top-down and bottom-up service leadership models.

4. Basic leadership competencies: intrapersonal competencies; IQ (task-relevant knowledge, problem solving, decision making); EQ (understanding and 
managing emotion effectively); AQ (adversity quotient); and SQ (spiritual quotient).

5. Basic leadership competencies: interpersonal competencies; communication skills (active listening, understanding, and using body language); positive social relationship building; and conflict resolution.

6. Character strengths and service leadership: the server is the service; basic character strengths (love of learning, honesty, courage, perseverance, humility, and gratitude).

7. Character strengths in Chinese philosophies; relevance of Confucian virtues to service leadership: integrity (lian), shame (chi), loyalty (zhong), filial piety (xiao), benevolence (ren), affection (ai), trustworthiness (xin), righteousness (yi), harmony (he), and peace (ping).

8. Caring disposition and service leadership; universal dimensions of social cognition (warmth and competence); love; and servant leadership.

9. Factors leading to creation, development and maintenance of positive social relationship: trust, fairness, respect, care, behavioral consistency, and loyalty.

10. Self-leadership: everyone is a leader; optimization of one's operating systems; personal branding; and selfmonitoring for improvement.

11. Developmental assets and service leadership: selfesteem, self-efficacy, purpose in life, and optimism about future.

12. Leaders as mentors: cognitive apprenticeship model; using master-apprentice style of learning; and leadership development as a process of constant learning.

To gauge the effects, the subject was piloted in one class with 60 students and multiple evaluation strategies were used for evaluation. The first evaluation strategy is objective outcome evaluation using a one group pretest-posttest design. Utilizing measures of positive youth development (such as measures of psychosocial competencies), life satisfaction, and service leadership qualities, positive changes in the students were observed over measures in behavioral competence, moral competence, general positive youth development qualities, moral character, and overall service leadership qualities [33].

Besides objective outcome evaluation, post-course subjective outcome evaluation was carried out [34]. Using a validated post-lecture evaluation tool, results showed that students perceived the subject content and teachers in a positive manner. Moreover, most of the students agreed that the subject was able to promote the development of service leadership qualities. Four-fifth or more of the students perceived that the subject was able to promote their social competence, ethical decision ability, compassion and care for other people, understanding of the importance of situational task competencies, character strength, and caring disposition in successful leadership, understanding the characteristics of successful service leaders, and synthesis of the characteristics of successful service leaders.

Using qualitative methods, students were also invited to complete reflection sheets by giving descriptors and metaphors about the subject [35]. Concerning the descriptors used by the students, they were overwhelmingly positive. Descriptors such as "inspiring", "interesting", "reflective", "meaningful", and "useful" were used by many students. Regarding the metaphors used by the students, they were also overwhelmingly positive. Some examples of the metaphors included "light bulb", "lantern”, "spiritual tour”, "pathway", "guidebook", "compass", and "mirror". Furthermore, findings based on focus groups also showed that the students felt that the subject was able to promote their service leadership qualities.

\section{Conclusion}

This chapter begins by discussing the concept of social entrepreneurship. Although there are different conceptions of the term, it is commonly believed that social entrepreneurs adopt the role of "change agent" who possesses a mission to create and sustain social value, has passion and compassion about people, pursues new opportunities to fulfill that mission, consciously work to overcome resources limitation, engages in continuous innovation, adaptation, and learning, and shows a heightened sense of accountability to the people he/she serves. We go on to discuss the attributes of successful social entrepreneurs. To some theorists, social entrepreneurs are leaders and intrapersonal and interpersonal leadership skills (such as resilience, cognitive competence, emotional competence, moral competence, and self-efficacy) are in fact underpinning the effective functioning of social entrepreneurs. As leadership qualities are important for social entrepreneurs, we argue that it is important to build up such foundational qualities in university students who are potential social entrepreneurs in future.

As far as leadership qualities are concerned, it is argued that the Service Leadership model developed by the Hong Kong Institute of Service Leadership and Management is a good model to be used. In the model, it is proposed that an effective service leader possesses basic 
leadership competencies (such as resilience and interpersonal communication skills), moral character and caring disposition. Conceptually speaking, these attributes closely match with the attributes of successful entrepreneurs (possession of leadership skills for effective functioning of social entrepreneurs, integrity, accountability, passion about people, and prosocial mentality).

In the last part of the chapter, a subject entitled "Service Leadership" offered at The Hong Kong Polytechnic University and the subject content are introduced. Besides, evaluation findings based on multiple evaluation strategies, including objective outcome evaluation, subjective outcome evaluation, qualitative evaluation, and process evaluation are briefly discussed. The evaluation findings suggest that the subject was able to promote the leadership qualities of the students, including psychosocial competence, moral character, and understanding of service leadership. It is argued that cultivation of leadership qualities in university students can help to build up the foundational qualities of potential social entrepreneurs for the future of Hong Kong.

Acknowledgments: The preparation for this manuscript and the Service Leadership project at The Hong Kong Polytechnic University are financially supported by Victor and William Fung Foundation.

\section{References}

1. Peredo AM, McLean M. Social entrepreneurship: a critical review of the concept. J World Bus 2006;41:56-65.

2. Dees JG. Taking social entrepreneurship seriously. Society 2007;44:24-31.

3. Huybrechts B, Nicholls A. Social entrepreneurship: definitions, drivers and challenges. In: Volkmann CK, Tokarski KO, Ernst K, editors. Social entrepreneurship and social business: an introduction and discussion with case studies. Wiesbaden, Germany: Springer-Gabler, 2012:34-48.

4. Mair J, Martí I. Social entrepreneurship research: a source of explanation, prediction, and delight. J World Bus 2006;41: 36-44.

5. Sullivan Mort G, Weerawardena J, Carnegie K. Social entrepreneurship: towards conceptualization. Int J Nonprofit Volun Sector Marketing 2003;8:76-88.

6. Chung P. Hong Kong Institute of Service Leadership and Management curriculum framework. Hong Kong: Hong Kong Institute of Leadership and Management, 2011.

7. Dees JG. The meaning of "social entrepreneurship". Available at: http://www.redalmarza.cl/ing/pdf/TheMeaningofsocialEntrepreneurship.pdf.

8. Say JB. A treatise on political economy or the production, distribution and consumption of wealth. New York: AM Kelley, 1971. (Original work published 1803).
9. Schumpeter JA. Capitalism, socialism and democracy, 6th ed. London: Taylor Francis e-Library, 2003. (Original work published 1943).

10. Drucker PF. Innovation and entrepreneurship. New York: Harper Row, 1985.

11. Stevenson HH, Roberts MJ, Grousbeck HI. New business ventures and the entrepreneur, 3rd ed. Homewood, IL: Richard D Irwin, 1989.

12. Austin J, Stevenson H, Wei-Skillern J. Social and commercial entrepreneurship: same, different, or both? Entrep Theory Pract 2006;30:1-22.

13. Abu-Saifan S. Social entrepreneurship: definition and boundaries. Technol Innovation Manage Rev 2012;2:22-7.

14. Bornstein D. Changing the world on a shoestring. Atlantic Monthly 1998;281:34-9.

15. Thompson J, Alvy G, Lees A. Social entrepreneurship a new look at the people and the potential. Manage Decis 2000;38:328-38.

16. Prabhu GN. Social entrepreneurial leadership. Career Dev Int 1999;4:140-5.

17. Weerawardena J, Sullivan Mort G. Investigating social entrepreneurship: A multidimensional model. J World Bus 2006;41:21-35.

18. Dolnicar S, Irvine H, Lazarevski K. Mission or money? Competitive challenges facing public sector nonprofit organisations in an institutionalised environment. Int J Nonprofit and Voluntary Sector Marketing 2008;13:107-17.

19. Tracey P, Phillips N. The distinctive challenge of educating social entrepreneurs: a postscript and rejoinder to the special issue on entrepreneurship education. Acad Manage Learn Edu 2007;6:264-71.

20. Dees JG. Enterprising nonprofits. Harvard Bus Rev 1998;76: 54-67.

21. Leadbeater C. The rise of social entrepreneurship. London: Demos, 1997.

22. Miller TL, Grimes MG, McMullen JS, Vogus TJ. Venturing for others with heart and head: how compassion encourages social entrepreneurship. Acad Manage Rev 2012;37:616-40.

23. Ernst K. Social entrepreneurs and their personality. In: Volkmann C, Tokarski K, Ernst K, editors. Social entrepreneurship and social business. Wiesbaden, Germany: Springer Gabler, 2012:51-64.

24. Hemingway CA. Personal values as a catalyst for corporate social entrepreneurship. J Bus Ethics 2005;60:233-49.

25. Penner LA, Finkelstein MA. Dispositional and structural determinants of volunteerism. J Pers Soc Psychol 1998;74:525-37.

26. Zahra SA, Gedajlovic E, Neubaum DO, Shulman JM. A typology of social entrepreneurs: motives, search processes and ethical challenges. J Bus Venturing 2009;24:519-32.

27. Waddock SA, Post JE. Social entrepreneurs and catalytic change. Public Admin Rev 1991;51:393-401.

28. Cukier W, Trenholm S, Carl D, Gekas G. Social entrepreneurship: a content analysis. J Strat Innovat Sustainabil 2011;7:99-119.

29. Short JC, Moss TW, Lumpkin GT. Research in social entrepreneurship: past contributions and future opportunities. Strat Entrep J 2009;3:161-94.

30. Brock D, Steiner S. Social Entrepreneurship education: is it achieving the desired aims? Proceedings of USASBE National Conference, 2008:1133-48. 
31. Smith BR, Kickul J, Coley L. Using simulation to develop empathy and motivate agency: an innovative pedagogical approach for social entrepreneurship education. In: Fayolle A, editor. Handbook of research in entrepreneurship education: international perspectives, vol. 3. Northampton, MA: Edward Elgar, 2010:13-24.

32. Shek DT, Yu L, Ma CM, Sun RC, Liu TT. Development of a creditbearing service leadership subject for university students in Hong Kong. Int J Adolesc Med Health 2013;25:353-61.
33. Shek DT, Yu L, Ma CM. The students were happy but did they change positively? Yes they did. Int J Disabil Hum Dev 2014;13:505-11.

34. Shek DT, Lin L, Liu TT. Service leadership education for university students in Hong Kong: Subjective outcome evaluation. Int J Disabil Hum Dev 2014;13:513-21.

35. Shek DT, Lin L, Liu TT, Law MY. Service leadership education for university students in Hong Kong: Qualitative evaluation. Int J Disabil Hum Dev 2014;13:523-29. 